\title{
2. BATHYMETRY OF THE GEORGIA BASIN AND ENVIRONS ${ }^{1}$
}

\author{
Carl Brenner and John LaBrecque ${ }^{2}$
}

This map (Fig. 1, in backpocket) represents a significant advance in bathymetric detail over our previous contouring efforts of the Georgia Basin area (LaBrecque et al., 1981; LaBrecque, 1986). Recently obtained bathymetric soundings from several new sources, most notably the Polar Duke site survey and the updated plotting sheets of the British and Argentine hydrographic offices, have substantially expanded the bathymetric data base for this still relatively underexplored region of the world's oceans (see Fig. 2). In addition, gravity anomalies derived from SEASAT altimetry data (Haxby et al., 1983; Haxby and LaBrecque, 1986) have provided insight into the morphology of certain bathymetric features that are not as yet fully defined by bathymetric soundings alone (Fig. 3). It should be noted, however, that all of the features shown on the map are at least partly supported by existing bathymetric data; no features are derived from SEASAT data only.

One of the difficulties in compiling a bathymetric map of this area is the advanced age of a large part of the data base. A great many of the ship tracks in the western South Atlantic are over $20 \mathrm{yr}$ old and thus, predate the routine use of satellite navigation. As a result, navigation data from these cruises are frequently unreliable. In some cases, the navigation data can be corrected by judiciously correlating track crossings with higher quality navigation from more recent cruises; in places, however, we have discarded whole strings of soundings as too ambiguous for confident manipulation.

During the period 1975-1978, the ARA Islas Orcadas (Argentine Naval Hydrographic Service) carried out extensive geophysical surveying in the South Atlantic under a joint program of the Argentine Naval Hydrographic Service and the U.S. National Science Foundation, Division of Polar Programs. The bathymetric data collected during these cruises, along with soundings from Conrad and Vema (Lamont-Doherty Geological Observatory-LDGO), Atlantis II (Woods Hole Oceanographic Institution), Glomar Challenger (Deep Sea Drilling Project), and Polar Duke comprise the predominant portion of the reliable data base in the area. Table 1 lists the data sources used in the compilation of the Figure 1 map.

The Polar Duke site survey was conducted in August and September of 1986. Extensive surveys were made of three proposed ODP drill sites, which were subsequently drilled on Leg 114 (Sites 698, 701, and 702). Bathymetry, magnetics, gravity, and single-channel seismic data were acquired. In addition, three cores and four dredges were recovered from seven bottom-sampling stations. The seismic system used a 400 -in. ${ }^{3}$ water gun and LDGO streamer. The quality of the magnetic, gravity, and seismic data is quite good, but the newly installed $3.5-$ and $12-\mathrm{kHz}$ systems on the site survey vessel did not function properly. As a result, bathymetric data from the cruise have been derived largely from the seismic-reflection data. Using this method, we

\footnotetext{
${ }^{1}$ Ciesielski, P. F., Kristoffersen, Y., et al., 1988. Proc. ODP, Init. Repts., 114: College Station, TX (Ocean Drilling Program).

2 Lamont-Doherty Geological Observatory of Columbia University, Palisades, NY 10964.
}

found excellent correlations with bathymetry from other cruises at data line crossings.

ODP Sites 699 and 700 were selected from preexisting singlechannel data collected by Islas Orcadas cruise 0775 , which defined the major features of the Georgia Basin.

The Georgia Basin spans about $500,000 \mathrm{~km}^{2}$. It lies on the South American plate and is bounded to the west by the eastern end of the Falkland Plateau (the Maurice Ewing Bank), to the north by the Falkland Ridge, and to the east by the Islas Orcadas Rise. To the south it is truncated by the South Georgia Platform and the forewall of the South Sandwich Trench. The Northeast Georgia Rise effectively divides the Georgia Basin into two sub-basins, sometimes referred to as the West and East Georgia basins. Magnetic anomaly studies indicate that basement age is Cretaceous throughout; anomaly M10 ( $130 \mathrm{Ma}$; Kent and Gradstein, 1986) has been identified in the western part of the basin, whereas the eastern basin terminates at the Islas Orcadas Rise in the Cretaceous magnetic quiet zone. The absence of identifiable magnetic anomalies in the eastern Georgia Basin requires that tectonic inference be used to date this part of the basin.

The Georgia Basin was formed by a series of tectonic events that began in the Late Cretaceous. Before the late Maestrichtian, there was an active spreading center to the south of the present-day Agulhas Fracture Zone Ridge in the eastern South Atlantic (duPlessis, 1977; Barker, 1979; LaBrecque and Hayes, 1979; LaBrecque, 1986; Raymond and LaBrecque, this volume). LaBrecque and Hayes (1979) proposed that convergence between the South American plate and the Mesozoic Malvinas plate generated the Northeast Georgia Rise during the Late Cretaceous. The Falkland and Agulhas ridges east of the Northeast Georgia Rise were probably generated during this period. At about chron $\mathrm{C} 29$, the end of the Cretaceous, the spreading axis jumped westward (LaBrecque and Hayes, 1979), displacing the Bouvet Triple Junction southwestward and initiating the formation of the Islas Orcadas and Meteor rises. The continued opening of the South Atlantic has subsequently separated these conjugate aseismic ridges. Since the Oligocene, the eastward motion of the South Georgia Platform and the South Sandwich plate has truncated the southern extent of the Georgia Basin and probably generated significant intrabasin deformation.

There are new features and reinterpretations in this map. We now believe, for example, that the Northeast Georgia Rise degenerates to a group of small seamounts north of $50^{\circ} \mathrm{S}$. This interpretation is supported by the SEASAT data set; the bathymetric data are ambiguous.

The Falkland Fracture Zone changes morphology near the intersection with the northern extension of the Northeast Georgia Rise, near $36^{\circ} \mathrm{W}, 49^{\circ} \mathrm{S}$. To the east of the rise, the Falkland Fracture Zone is a single ridge with an average relief of $2500 \mathrm{~m}$. The oceanographically important Falkland Gap is at the intersection, and to the west of the intersection, the Falkland Ridge is a double ridge with less relief $(1500 \mathrm{~m})$, which extends to the northern margin of the Falkland Plateau. It should be noted that little high-quality geophysical data are available in the region of the Falkland Gap. Hence, the nearby morphology and crustal structure are speculative. 


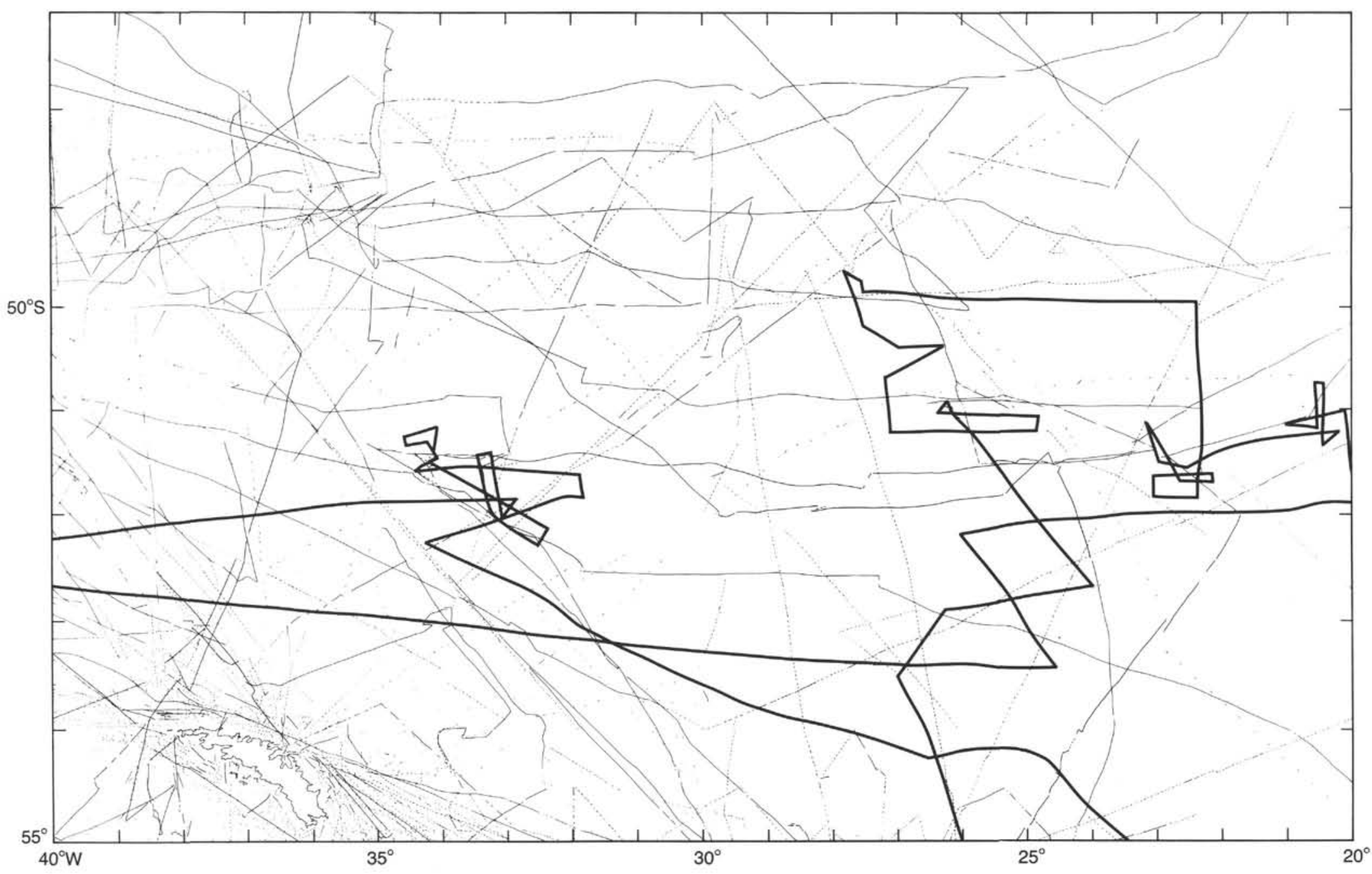

Figure 2. Track chart showing the bathymetric data base used in the compilation of the Figure 1 map. The Polar Duke site survey track is shown with a heavy line. 


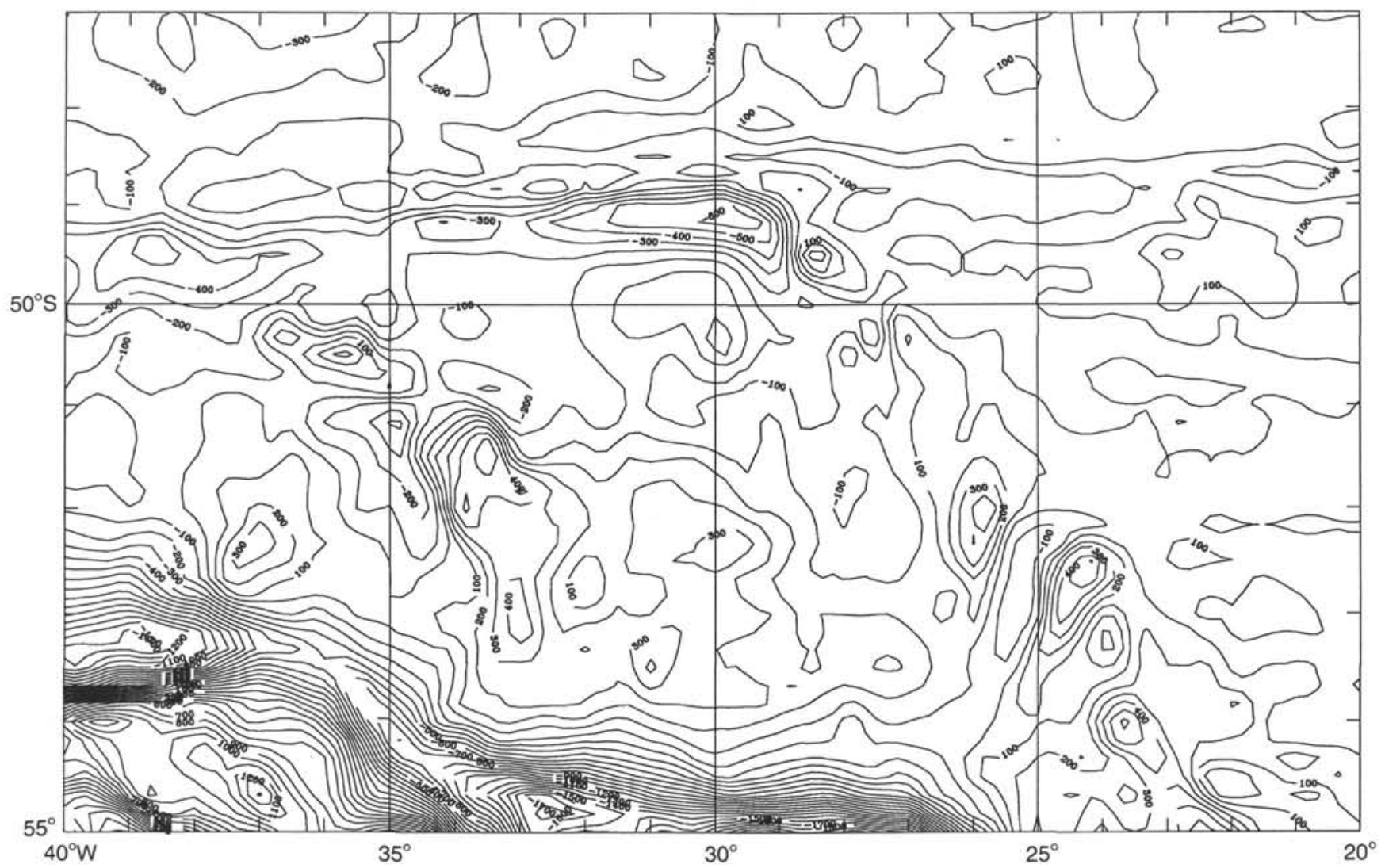

Figure 3. Contour map of the SEASAT gravity field. The contour interval is 10 mgals.

Table 1. Sources of bathymetric soundings.

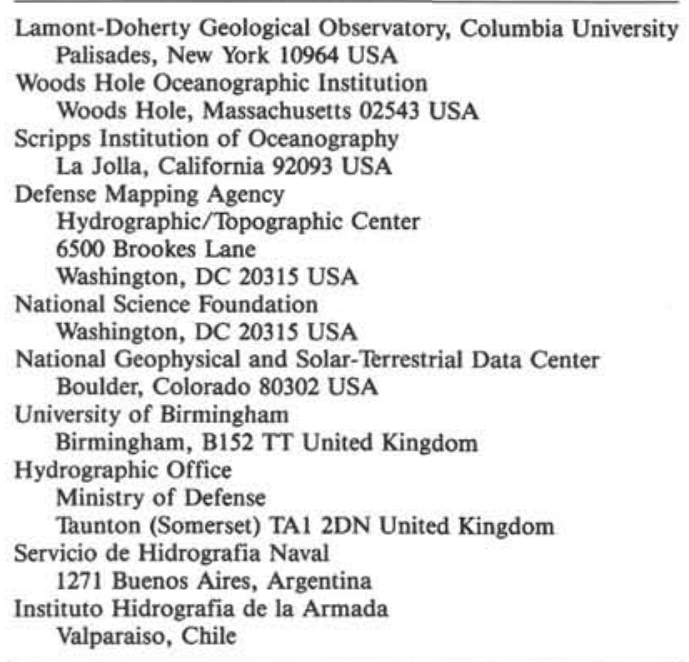

We have also mapped, for the first time, a small but prominent ridge (named Soledad) on the eastern flank of the Northeast Georgia Rise. Located roughly between $53^{\circ}$ and $53.5^{\circ} \mathrm{S}$, the Soledad ridge has the same orientation as the southeastern part of the rise and exhibits a relief of about $1000 \mathrm{~m}$. Examination of the seismic-reflection profiles reveals that it is a basement feature and that bottom-water currents have scoured a channel on its southeastern flank.

The morphology of the Islas Orcadas Rise is better defined with the addition of the Polar Duke data set. The feature, as de- fined by the $4000-\mathrm{m}$ isobath, becomes quite narrow at about $50^{\circ} \mathrm{S}$, before broadening considerably to the south and transforming into a southwestward-trending lineament of seamounts south of $53^{\circ} \mathrm{S}$. Similar but more extensive "pinching" is also evident at the conjugate region of the northern Meteor Rise, in the Agulhas Basin (LaBrecque et al., 1981; Raymond and LaBrecque, this volume). The Islas Orcadas Rise, and to some extent the Meteor Rise, appear to be dissected by transverse valleys that extend into fracture zones of the present-day mid-ocean ridge system (LaBrecque, 1986; Cande et al., in press). The structure is clearly displayed in the SEASAT gravity maps. This segmentation of the rises probably reflects enhanced volcanic effusion from magma chambers during initial rifting. Continuation of the spatial distribution of these spreading cells into the present-day mid-Atlantic illustrates the stability of the spreading system.

\section{ACKNOWLEDGMENTS}

We are grateful to Carol Raymond, Steve Cande, and Paul Ciesielski for their useful comments concerning the map and this text. Tom Aitken was helpful in the preparation of the digital data base. The map was drafted by Ana Maria Alvarez.

Financial support for this cruise was provided by OCE 85-07681. We wish to thank Captain Mueller and the crew of the Polar Duke and ITT Antarctic Services for their great effort in supporting the site survey.

It is with great sadness that we have named Soledad Ridge in memory of Soledad Valdiva, a member of the Polar Duke scientific party and a graduate student of the University of Chile, who met with a tragic death shortly after the cruise.

\section{REFERENCES}

Barker, P. F., 1979. The history of ridge-crest offset at the Agulhas Fracture zone from a small-circle geophysical profile. Geophys. J. R. Astron. Soc., 59:131-145. 
Cande, S. C., LaBrecque, J. L., and Haxby, W. F., in press. Plate kinematics of the South Atlantic: Chron 34 to Present. J. Geophys. Res.

duPlessis, A., 1977. Seafloor spreading south of the Agulhas Fracture Zone. Nature, 270:719-721

Haxby, W. F., Karner, G. D., LaBrecque, J. L., and Weissel, J. K., 1983. Digital images of combined oceanic and continental data sets and their use in tectonic studies. Eos, Trans. Am. Geophys. Union, 64: 995-1004.

Haxby, W. F., and LaBrecque, J. L., 1986. SEASAT derived gravity fields. In LaBrecque, J. L. (Ed.), South Atlantic Ocean and Adjacent Continental Margin, Atlas 13: Ocean Margin Drilling Program Reg. Atlas Ser., 13:

Kent, D. V., and Gradstein, F. M., 1986. A Jurassic to Recent chronology. In Tucholke, B. E., and Vogt, P. R. (Eds.), The Geology of North America: The Western Atlantic Region: Geol. Soc. Am. DNAG Ser., 1.

LaBrecque, J. L. (Ed.), 1986. South Atlantic Ocean and Adjacent Continental Margin, Atlas 13: Ocean Margin Drilling Program Reg. Atlas Ser., 13.
LaBrecque, J. L., and Hayes, D. E., 1979. Seafloor spreading history of the Agulhas basin. Earth Planet. Sci. Lett., 45:411-428.

LaBrecque, J. L., Rabinowitz, P. D., and Brenner, C., 1981. General Bathymetric Chart of the Oceans (GEBCO 5:16): Ottawa (Canadian Hydrographic Office).

Lorenzo, J. M., and Mutter, J. C., in press. Seismic stratigraphy and tectonic evolution of the Falkland/Malvinas Plateau. Rev. Bras. Geoscienc.

Rabinowitz, P. D., Cande, S. C., and LaBrecque, J. L., 1976. The Falkland escarpment and Agulhas Fracture Zone: the boundary between oceanic and continental crust at conjugate continental margins. An. Acad. Bras. Cienc., 48:241-251.

Shipboard Scientific Party, Harris, W., and Sliter, W. V., 1976. Evolution of the Southwestern Atlantic Ocean Basin: Results of Leg 36, Deep Sea Drilling Project. In Barker, P., Dalziel, I.W.D., et al., Init. Repts. DSDP, 36: Washington (U.S. Govt. Printing Office), 9931014.

\section{Ms 114A-102}

